\title{
Comparison of Two Different Applications of Proprioceptive Neuromuscular Facilitation Techniques to Increase Upper- Extremity Muscle Strength
}

\section{Üst Ekstremite Kas Kuvvetinin Artırılmasında Proprioseptif Nöromusküler Fasilitasyon Tekniklerinin İki Farklı Şekilde Uygulanmasının Karşılaştırılması}

(i) Hasan Atacan TONAK¹, id Nihal BÜKER², ib Ali KiTiş², ib Erdoğan KAVLAK²

${ }^{1}$ Akdeniz University Faculty of Health Sciences, Department of Physiotherapy and Rehabilitation, Antalya, Turkey

2Pamukkale University School of Physical Therapy and Rehabilitation, Denizli, Turkey

\begin{abstract}
Objective: The aim of this study to investigate the efficacy of bilateral symmetrical proprioceptive neuromuscular facilitation (PNF) patterns in increasing the muscle strength in the upper extremity by comparing their combination with elastic resistance band (ERB) use versus physiotherapist-administered programs.

Methods: Participants were randomly divided into two groups (PNF, elastic resistance band). The strength increasing exercise program was administered to the participants of both groups 3 days a week for 6 weeks. All participants were evaluated before and after exercise program. The circumferences of the upper extremities and hand grip strengths were evaluated. The push-up and dip-strength tests were performed to evaluate the endurance of the arm and the shoulder girdle.

Results: A total of 40 individuals in the age range from 20 to 25 years [(PNF group: $\overline{\mathrm{X}} \pm$ standard deviation $(\mathrm{SD})=21.80 \pm 1.05$ years; $E R B$ group: $\bar{X} \pm S D=21.40 \pm 1.66$ years] were included in this study. The comparison of before and after the exercise revealed that there was a statistically significant increase in the arm and forearm circumferences of both extremities in the both groups after the training $(\mathrm{p}<0.05)$. The groups comparisons demonstrated that there were no statistically significant change differences in
\end{abstract}

\section{ÖZ}

Amaç: Çalış̧anın amacı bilateral simetrik proprioseptif
nöromüsküler fasilitasyon (PNF) paternlerinin üst ekstremite
kas kuvvetinin artırılmasında fizyoterapist tarafından uygulanan
programlara karşı elastik dirençli bant (EDB) ile uygulanan
kombinasyonunun karşııslaştırılmasıdır.

Yöntemler: Katılımcılar randomize olarak iki gruba ayrıldı (PNF, elastik dirençli bant). Kuvvetlendirme egzersizleri her iki gruptaki katılımcilara 6 hafta boyunca haftada 3 gün uygulandı. Bütün katılımcılar egzersiz programının öncesinde ve sonrasında değerlendirildi. Üst ekstremite çevre ölçümleri ve kavrama kuvvetleri değerlendirildi. Kol ve omuz kuşağının enduransı değerlendirmek için push-up ve dip-strength testleri uygulandı.

Bulgular: Çalışmaya yaşları 20 ile 25 arasında değişen (PNF grubu: $\overline{\mathrm{X}} \pm$ standart sapma (SS) $=21,80 \pm 1,05$ yll; EDB grubu: $\overline{\mathrm{X}} \pm$ SS $=21,40 \pm 1,66$ yil] 40 birey dahil edildi. Egzersiz öncesi ve sonrası karşılaşıırmalarda, her iki grupta da iki üst ekstremitesinin kol ve önkol çevre ölçümlerinde egzersiz sonrasında istatistiksel olarak bir artışın olduğunu gösterdi $(\mathrm{p}<0,05)$. Grupların karşılaşııımalarında, kol, önkol ve el bileği çevre ölçümlerinde ve push-up ve dip-strength tekrar sayılarında istatistiksel olarak değişiklik olmadığını gösterdi $(\mathrm{p}>0,05)$.

Address for Correspondence: Hasan Atacan TONAK, Akdeniz University Faculty of Health Sciences, Department of Physiotherapy and Rehabilitation, Antalya, Turkey

E-mail: atacantonak@akdeniz.edu.tr ORCID ID: orcid.org/0000-0002-3545-936X

Cite this article as: Tonak HA, Büker N, Kitiş A, Kavlak E. Comparison of Two Different Applications of Proprioceptive Neuromuscular Facilitation Techniques to Increase Upper-Extremity Muscle Strength. Bezmialem Science 2021;9(2):190-7. 
the circumferences of the arms, forearms, and the wrists of both extremities; and the number of push-ups and dip-strength repeats ( $\mathrm{p}>0.05)$.

Conclusion: This study demonstrated that PNF patterns can be used in these two different modes of administration (with ERB and manually by the physiotherapist) to increase the muscle strength and improve endurance in the upper extremity and that none of them was superior to the other.

Keywords: Strength, upper extremity, exercise
Sonuç: Bu çalışma üst ekstremiteye yönelik kuvvetlendirme ve endurans eğitiminde PNF paternlerinin iki farklı şekilde (elastik dirençli bant ile ve fizyoterapist tarafindan manuel olarak) kullanılabileceğini ve birbirlerine üstünlüğü olmadığı gösterdi.

Anahtar Sözcülkler: Kuvvet, üst ekstremite, egzersiz

\section{Introduction}

Proprioceptive neuromuscular facilitation (PNF) techniques were developed by Margaret Knott, Dorothy Voss, and Dr. Herman Kabat in the 1940s for rehabilitation treatment (1). PNF techniques are mainly used to improve functional ability and existing muscle strength (1). PNF is mainly based on the principle that physiological human motion is characterized by rotational and oblique patterns, which can be improved by resistance exercises performed against a maximum level of resistance (2). PNF aims to improve posture and range of motion by utilizing tactile, visual, and verbal stimuli (1-3).

PNF exercises are characterized by rhythmic motions of the joints and the contraction of muscles against maximum resistance. PNF's theoretical principles are based on the stimulation of proprioceptors to improve the neuromuscular system's responses (4). PNF is generally an effective method to increase joint range of motion, muscle strength, endurance, and stabilization. It also improves joint position sense, coordinated movements, and flexibility $(3,5)$. PNF is particularly used in athletic training programs to increase flexibility, coordination, muscle strength, and performance $(2,6)$. Studies have shown that PNF is efficacious in increasing muscle strength $(7,8)$. Surburg and Schrader (9) reported that the repeated contractions technique is the most preferred and the most effective method, especially to increase upper extremity muscle strength.

Studies have shown that elastic resistance band (ERB) use in PNF increased muscle strength, range of motion, flexibility, and the patient's participation in daily living activities when used for rehabilitation purposes $(10,11)$. Studies have been published using PNF exercises to increase muscle strength $(12,13)$. PNF exercises applied manually by a physiotherapist cause a significant increase in muscle strength $(6,12)$. Moreover, studies suggest that PNF exercises with an ERB increase muscle strength $(10,14)$. ERBs are commonly used in clinics because of their affordable price, ease of application, and safety (10). Nevertheless, the most common technique used in clinics is PNF exercises applied manually by a physiotherapist $(2,13)$. However, no study investigated and compared the effects of these two techniques, commonly used in clinics to strengthen the upperextremity muscles. Our study was designed to investigate ERB use's efficacy versus a physiotherapist-administered program in applying bilateral symmetrical PNF patterns to increase upper- extremity muscle strength, considering that the resistance would be adjusted manually by the physiotherapist and thereby the sensitive inputs would be more effective in the latter mode of application.

\section{Methods}

This study was approved by the non-interventional ethics committee (B.30.2.PAÜ.0.20.05.09/126). The informed consent process was completed after the eligible individuals were informed about the study, and then they signed the informed consent documents.

\section{Study Population}

The study included 40 university students, whose ages ranged from 20 to 25 years old, who agreed to participate in the study, and who had no disease or disability diagnoses that would impair upper-extremity performance as confirmed by a specialist physician. Patients who had a limited range of motion in the upper extremities, who had undergone upper-extremity surgery in the last six months, had any chronic neurological, musculoskeletal, metabolic, rheumatologic, or psychiatric disorders that would affect upper-extremity performance were excluded from the study.

\section{Assessment Methods}

Forty participants were randomly divided into two groups, namely the PNF and ERB groups, using gender-based block randomization. All participants were evaluated before and after the 6-week exercise program by the same physiotherapist, who was experienced in orthopedic rehabilitation and was not informed of the study details.

Descriptive information was collected from the participants and documented in a form developed for the study. The anthropometric measurements of the circumferences of the arms, forearms, and wrists were taken from both of the participants' upper extremities using a standard tape measure (15). The wrist circumference was measured while the participant was standing with both palms rotated toward each other, the arms facing the body, and the elbow flexed at $90^{\circ}$. Hence, the tape measure was in full contact with the styloid processes of the radius and ulna. While measuring the mid-forearm circumference, the forearm length was first measured by measuring the distance between the olecranon and the styloid process of the radius and calculating 
the midpoint of the forearm. The circumference was then measured from this point with the arm in the same position as in the wrist circumference measurement. For the mid-arm circumference measurement, the distance between the acromion and the olecranon was first measured in the same position as in the wrist and forearm circumference measurements. The arm length measurement was recorded, and the midpoint of the arm was calculated. The circumference was then measured from this point, and all anthropometric circumference measurement results were recorded (15). A Baseline ${ }^{\circledR}$ hydraulic hand dynamometer was used to evaluate handgrip strength, measured according to the standard measurement method described by the American Society of Hand Therapists. Each measurement was repeated three times, and the mean of these three measurements was recorded as the handgrip strength in kilograms (16).

The push-up test was performed to evaluate arm and shoulder girdle endurance. The test started when the participant was in a prone position with his/her arms and elbows flexed. Then, the participant was asked to push up his/her head, shoulders, and trunk by bringing their elbows into full extension. The test position was applied in men and women differently; men were asked to have their trunk and lower extremities in full extension, whereas women were asked to have their trunk in extension and knees in flexion. The test continued until the participant felt fatigued. The number of repetitions was recorded as the score (17). The dip-strength test was used for measuring the shoulder girdle and the upper-extremity endurance during vertical elevation movement and the push up. The participant was asked to push up until his/her elbows were fully extended while they supported themselves with their hands using the parallel bar. The test continued until the participant felt fatigued, and the correct number of repetitions was recorded as the score (18). The participants took three-minute rest intervals between the tests to control for the potential confounding effects of fatigue.

\section{Training}

A physiotherapist performed participants' assessments in both groups after the assessments were over, PNF exercises were taught to all participants. The exercises were carried out by the physiotherapist for 20 participants in the PNF group, three days a week for 6 weeks. The participants in the ERB group performed their 6-week exercise programs under the physiotherapist's supervision. They were verbally warned by the physiotherapist to avoid any wrong exercises and correct wrong exercises. Participants in both groups were trained on the bilateral symmetrical PNF patterns of the upper extremities in two different diagonals (flexion-adduction-external rotation, extension-abduction-internal rotation; flexion-abductionexternal rotation, extension-adduction-internal rotation) in the sitting position on a chair with their backs supported. The exercise programs to increase strength were administered to participants of both groups three days a week for six weeks, for 18 sessions per participant. Exercises started with four repetitions that were increased until ten repetitions were achieved progressively in time (14).

\section{Proprioceptive Neuromuscular Facilitation (PNF) Group}

PNF group participants were administered the muscle strength increase program while sitting on a chair with back support. Bilateral symmetrical PNF patterns of the upper extremity were applied using the repeated contractions technique. PNF group participants performed their exercises with a physiotherapist. The repeated contraction technique was used to increase upperextremity muscle strength. When starting the exercise, the muscles were first put in their longest positions, and isotonic contractions were stimulated with stretching. With verbal commands, the exercise was performed with isotonic and isometric contractions after stretching. Isometric contractions were performed by commanding "hold" at every point where the movement was weakened. Isotonic and isometric contractions were repeated and applied until the endpoint of the pattern, where the agonist muscles were in the shortest position. During the exercise, the physiotherapist acted diagonally with the participant without interrupting the hand contact to prevent the movement's completion $(2,19)$. A resting period of three minutes was allowed in the interval between each training session.

\section{Elastic Resistance Band (ERB) Group}

Red, blue, green, and black colored bands (Thera-Band ${ }^{\circledR}$, Hygenic Corporation, Akron, OH, USA) were used during ERB technique application. The study of Areas et al. (14) was the reference to select the bands. The appropriate band was selected for each participant based on their performance after a baseline assessment with one maximum repeat test using a red TheraBand (14). The Thera-Band ${ }^{\circledR}$ website was used to comply with the elastic resistance bands' user guidelines (20).

After selecting the appropriate ERB color, completing the training program, and confirming proper band use, the participant performed the upper-extremity bilateral symmetrical patterns in the same sitting position on a chair with back support under the physiotherapist's supervision. A resting period of three minutes was applied in the interval between each training session.

\section{Statistical Analysis}

Windows-based SPSS (IBM SPSS Statistics, Version 23.0, Armonk, NY, USA) package program was used to analyze the study data. The number of participants to be included in the study was determined to be 12 based on the power analysis results at $\alpha=0.05$ and $\beta=0.20$ (for $80 \%$ power) (14). Considering that potentially $25 \%$ of data could be lost, 15 individuals were included in each group to participate in the 6-week exercise program. Analytical (Kolmogorov-Smirnov/Shapiro-Wilks tests) and visual (histograms and probability graphs) methods were used to test data conformity to a normal distribution. Descriptive statistics are presented as mean \pm standard deviation $(\overline{\mathrm{X}} \pm \mathrm{SD})$ and percentages. The Mann-Whitney $\mathrm{U}$ test was used for testing intergroup differences. The Wilcoxon test was used for determining intragroup differences. The level of statistical significance was accepted to be $\mathrm{p}<0.05$ in this study. 


\section{Results}

A total of 40 individuals ranging in age from 20 to 25 years old (PNF group: $\overline{\mathrm{X}} \pm \mathrm{SD}=21.80 \pm 1.05$ years; $\mathrm{ERB}$ group: $\overline{\mathrm{X}} \pm \mathrm{SD}$ $=21.40 \pm 1.66$ years) were included in this study. Other participant demographic information is presented in Table 1. Before the exercises, there were no statistically significant intergroup differences in the circumferences of the arms, forearms, and wrists of the dominant and nondominant extremities and the number of push-ups and dip-strength repeats ( $p>0.05)$ (Table 2).

The intragroup comparison of the data collected before and after the exercises revealed a statistically significant increase in both extremities' arm and forearm circumferences in the PNF group after the exercise $(\mathrm{p}<0.001)$. Also, there was a statistically significant increase in the PNF group in the number of dipstrength repetitions than pre-exercise values $(\mathrm{p}<0.001)$. No statistically significant differences were observed in the wrist circumference, grip strength, and the number of push-up repeats of both upper extremities compared with pre-exercise values ( $>0.05)$ (Table 3). In the ERB group, there was a statistically significant difference in the arm and forearm circumferences of both extremities and the dominant extremity's wrist circumference compared with pre-exercise values $(\mathrm{p}<0.05)$. Also, there was a statistically significant increase in the number of push-ups and dip-strength repetitions compared with preexercise data $(p<0.05)$. There were no statistically significant differences in the wrist circumference of the nondominant arm and the grip strength of both upper extremities after exercise ( $>0.05)$ (Table 3).

The intergroup comparisons demonstrated that there were no statistically significant differences in the change in the circumferences of the arms, forearms, and wrists of both

\section{Table 1. Participant demographic data}

\begin{tabular}{|c|c|c|c|c|c|}
\hline \multirow{3}{*}{ Variables } & \multicolumn{4}{|l|}{ Groups } & \multirow{3}{*}{$\mathrm{p}^{\mathrm{a}}$} \\
\hline & \multicolumn{2}{|c|}{ PNF group $(n=20)$} & \multicolumn{2}{|c|}{ ERB group $(n=20)$} & \\
\hline & $\min -\max$ & $\bar{X} \pm S D$ & $\min -\max$ & $\overline{\mathrm{X}} \pm \mathrm{SD}$ & \\
\hline Age (years) & $20-23$ & $21.80 \pm 1.05$ & $20-24$ & $21.40 \pm 1.66$ & 0.568 \\
\hline Height $(\mathrm{cm})$ & $156-187$ & $170.40 \pm 9.68$ & $155-183$ & $167.65 \pm 7.43$ & 0.621 \\
\hline Weight $(\mathrm{kg})$ & $50-84$ & $65.15 \pm 12.62$ & $45-80$ & $58.90 \pm 10.42$ & 0.209 \\
\hline BMI $\left(\mathrm{kg} / \mathrm{m}^{2}\right)$ & $17.72-26.22$ & $22.19 \pm 2.40$ & $16.52-26.73$ & $20.83 \pm 2.64$ & 0.172 \\
\hline & $\mathbf{n}$ & $\%$ & $\mathrm{n}$ & $\%$ & \\
\hline Hand domin & & & & & \\
\hline Right & 20 & 100 & 20 & 100 & \\
\hline Left & 0 & 0 & 0 & 0 & \\
\hline
\end{tabular}

Table 2. Comparison of anthropometric measurements, grip strengths and endurances of groups before training

\begin{tabular}{|c|c|c|c|}
\hline Variables & $\begin{array}{l}\text { PNF group } \\
\bar{X} \pm S D\end{array}$ & $\begin{array}{l}\text { ERB group } \\
\bar{X} \pm S D\end{array}$ & $\mathrm{p}^{\mathrm{a}}$ \\
\hline \multicolumn{4}{|c|}{ Arm circumference $(\mathrm{cm})$} \\
\hline Non-dominant & $25.39 \pm 2.96$ & $24.27 \pm 3.18$ & 0.110 \\
\hline \multicolumn{4}{|c|}{ Forearm circumference (cm) } \\
\hline \multicolumn{4}{|c|}{ Wrist circumference (cm) } \\
\hline Dominant & $15.84 \pm 1.40$ & $15.47 \pm 1.41$ & 0.383 \\
\hline Non-dominant & $15.76 \pm 1.35$ & $15.47 \pm 1.41$ & 0.556 \\
\hline \multicolumn{4}{|l|}{ Grip strength (kg) } \\
\hline Dip-strength (гр) & $7.47 \pm 6.99$ & $4.65 \pm 3.36$ & 0.113 \\
\hline
\end{tabular}


extremities; and in the change in the number of push-ups and dip-strength repeats $(\mathrm{p}>0.05)$ (Table 4).

\section{Discussion}

This study was designed to reveal the difference between the two different modes of PNF administration to increase the strength in the upper-extremity muscles, namely the repeated contractions method applied by a physiotherapist and PNF patterns with ERB under the supervision of a physiotherapist. It showed that the extremity circumferences and endurance were increased in both groups with no intergroup differences. Neither of the two PNF administration modes was superior in improving upper-extremity muscle strength and performance when the PNF manual repeated contractions technique applied by the physiotherapist was compared with ERB use in PNF under the supervision of the physiotherapist.

Table 3. Comparison of anthropometric measurements, grip strengths and endurances before and after training

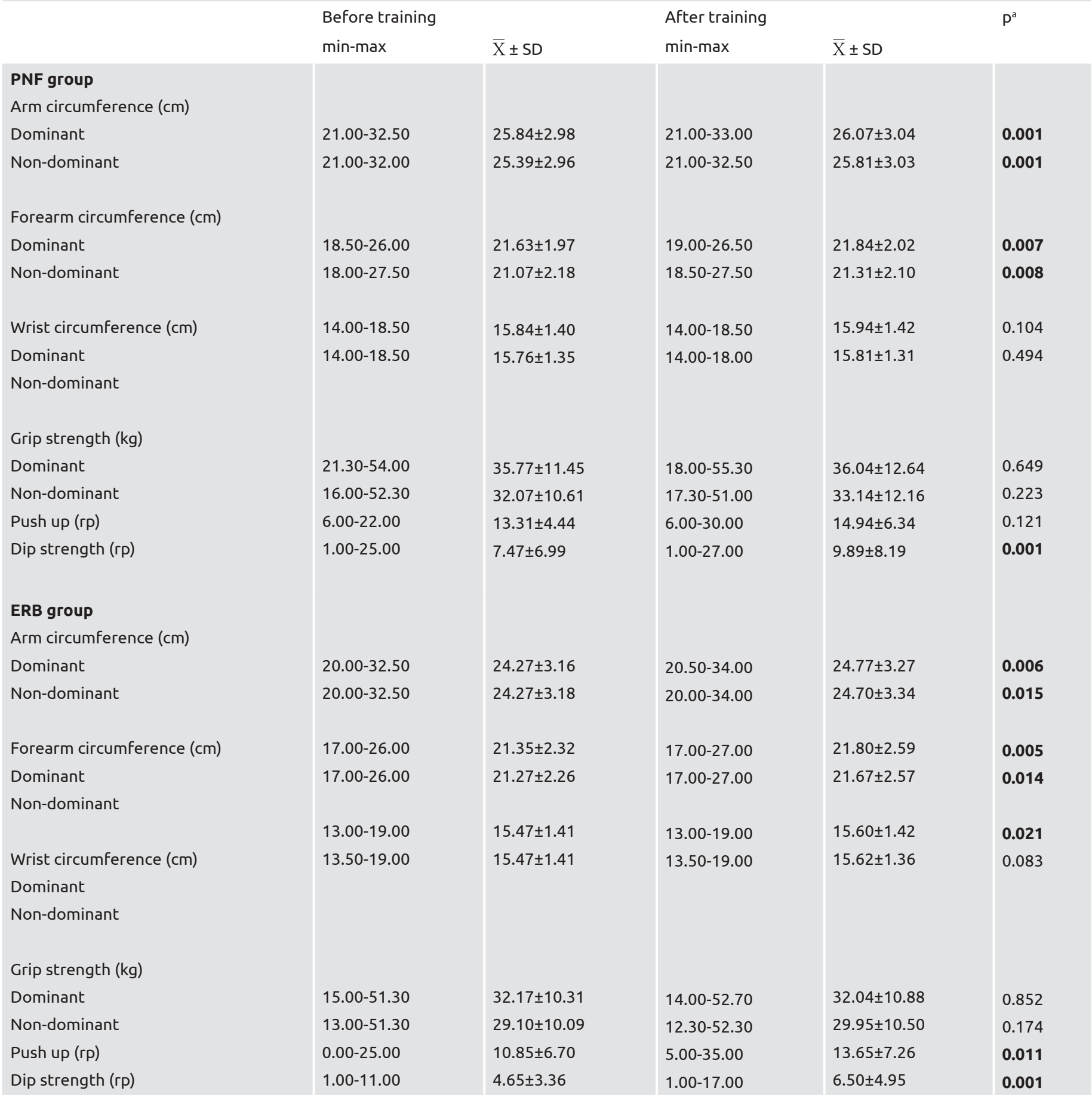

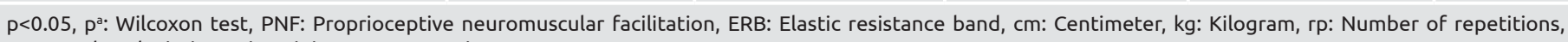
SD: Standart deviation, min: Minimum, max: Maximum 
Although no consensus has been achieved on how PNF techniques act on muscle strength and performance, these techniques are utilized in practice to increase muscle strength and performance, as reported in the literature $(2,6,7)$. However, some studies have reported that PNF techniques cause a decrease in muscle strength during the acute period $(13,21)$. These studies suggest that this effect might be caused by an acute inhibitory response in the neural pathways due to PNF's facilitatory or inhibitory effects on muscle spindle receptors and the Golgi tendon organ (22). Furthermore, the reduction in transferred forces to the musculoskeletal system in the acute period after PNF exercises may be another reason leading to a decrease in muscle strength and performance (23). Studies investigating the chronic effects of PNF exercises on muscle strength provided evidence that PNF techniques increased muscle strength compared with the data reported on acute effects $(8,10)$.

In different studies using PNF patterns and techniques for lower extremity strengthening, it was demonstrated that PNF exercises combined with ERB increased muscle strength in the lower extremities (10) and improved the ankle flexor muscles' strength, improving the walking speed (11). In another study on patients with bilateral scapular winging, PNF exercises were applied to the upper extremity; it was reported that muscle strength and scapular endurance were increased (24). These data demonstrate that PNF exercises are used less commonly to increase muscle strength in the upper extremities compared with the lower extremities. Therefore, there is no sufficient information in the literature about PNF to increase muscle strength in the upper extremity. In this study, we found that PNF patterns did not affect grip strength in two different ways but increased the forearm and arm circumferences in both groups. Studies in the literature report that grip strength varies depending on anthropometric parameters (the arm length, arm circumference, forearm length, and forearm circumference), hand dominance, gender, height, body mass index, age, and nutrition) $(15,25)$. Considering this published information, we thought that the absence of differences in the handgrip strength before and after the exercises might have been due to the differences in the measured values of the participants' anthropometric parameters. Furthermore, it is reported that muscle strength is affected by the mass, physiological cross-sectional areas, and the regulation of the muscles' leverage mechanisms rinvolved in performing the movement (26).

Endurance is essential to achieve functionality and performance in the upper extremity. Therefore, it is an important component of physical fitness (27). Muscle strength plays an important role in improving endurance (28). Muscle strength depends on the type of muscle, its contraction rate, the contraction type, and the joint position sense regulated by the proprioceptive system (3). Improvements in muscle strength may also be reflected in endurance. Studies are available in the literature investigating the effects of upper-extremity PNF exercises on muscle strength $(6,24)$. In this regard, the present study differs from other similar studies in the literature because we also investigated the effects of PNF exercises on endurance, using the push-up and dip-strength tests. We observed a statistical increase in endurance after a 6-week exercise program in both the PNF and the ERB groups. However, there was not an intragroup difference. The studies in the literature are parallel with our study results since they reported improvements after evaluating PNF exercises' effects on endurance and performance $(2,17)$.

Studies revealed that muscle-tendon length and the muscle's physiological cross-sectional area were increased with PNF

Table 4. Comparison of change differences in anthropometric measurements, grip strength, and endurance before and after training

\begin{tabular}{|c|c|c|c|}
\hline Variables & $\begin{array}{l}\text { PNF group } \\
\Delta \pm \mathrm{SD}\end{array}$ & $\begin{array}{l}\text { ERB group } \\
\Delta \pm \mathrm{SD}\end{array}$ & $\mathrm{p}^{\mathrm{a}}$ \\
\hline \multicolumn{4}{|c|}{ Arm circumference $(\mathrm{cm})$} \\
\hline Dominant & $0.23 \pm 0.25$ & $0.50 \pm 0.72$ & 0.114 \\
\hline Non-dominant & $0.42 \pm 0.44$ & $0.43 \pm 0.71$ & 0.416 \\
\hline \multicolumn{4}{|c|}{ Forearm circumference (cm) } \\
\hline Dominant & $0.21 \pm 0.30$ & $0.45 \pm 0.62$ & 0.109 \\
\hline Non-dominant & $0.24 \pm 0.34$ & $0.40 \pm 0.66$ & 0.061 \\
\hline \multicolumn{4}{|c|}{ Wrist circumference $(\mathrm{cm})$} \\
\hline Dominant & $0.10 \pm 0.26$ & $0.13 \pm 0.22$ & 0.154 \\
\hline Non-dominant & $0.05 \pm 0.32$ & $0.15 \pm 0.36$ & 0.530 \\
\hline \multicolumn{4}{|l|}{ Grip Strength (kgs) } \\
\hline Dominant & $0.27 \pm 2.53$ & $-0.13 \pm 3.08$ & 0.790 \\
\hline Non-dominant & $1.07 \pm 3.67$ & $0.85 \pm 2.70$ & 0.411 \\
\hline Push up (гр) & $1.63 \pm 4.37$ & $2.80 \pm 4.43$ & 0.541 \\
\hline Dip strength (гр) & $2.42 \pm 2.52$ & $1.85 \pm 2.23$ & 0.487 \\
\hline
\end{tabular}


techniques $(4,8)$. After a 6-week PNF exercise program, the observed increases in the anthropometric measurements of participants' arms and forearms in both study groups support the conclusion that PNF increases muscles' physiological crosssectional area. This cross-sectional area and the length-strain relationship generate a larger force and improve endurance (14). The resistance applied during PNF exercises provides sensory input about the motion's direction, thereby increasing awareness. Consequently, motor control and motor learning are facilitated. Afferent pathways and receptor stimulation facilitate muscle contraction mechanisms. It is known that improved neuromuscular adaptation increases muscle strength $(2,4,6)$. This study found out that neither method was superior regarding the results of anthropometric parameters, increases in muscle strength, and improvements in endurance in the upper extremities when the outcomes of the two methods were compared at the end of a 6-week PNF exercise program.

\section{Study Limitations}

This study has strengths and limitations. One of this study's strengths is that the data were collected using a safe, objective, and standardized methodology. The participants were evaluated before and after the training by the same physiotherapist, who was uninformed of the study details. Another study strength was that the exercises in the ERB group were adjunctively supervised by the physiotherapist. However, the lack of information about the long-term results can be listed as this study's limitation.

\section{Conclusion}

This study has demonstrated that PNF techniques could be used in the abovementioned two different administration modes to increase muscle strength and endurance in the upper extremity. Neither mode is superior to the other. We think that the clinical environment's characteristics, the physiotherapist's working environment, schedule, and patient factors need to be considered for selecting the appropriate exercise type.

\section{Ethics}

Ethics Committee Approval: Pamukkale University NonInterventional Clinical Research Ethics Committee approval was obtained for the study (B.30.2.PAÜ.0.20.05.09/126).

Informed Consent: Signed informed consent form was obtained from all participants.

Peer-review: Externally peer reviewed.

\section{Authorship Contributions}

Surgical and Medical Practices: H.A.T., N.B., A.K., E.K., Concept: N.B., A.K., Design: H.A.T., N.B., A.K., E.K., Data Collection or Processing: H.A.T., N.B., A.K., E.K., Analysis or Interpretation: N.B., A.K., E.K., Literature Search: H.A.T., N.B., Writing: H.A.T., N.B., A.K., E.K.

Conflict of Interest: No conflict of interest was declared by the authors.
Financial Disclosure: The authors declared that this study received no financial support.

\section{References}

1. Stone JA. Proprioceptive Neuromuscular Facilitation. Athletic Therapy Today 2000;5:38-9.

2. Hindle KB, Whitcomb TJ, Briggs WO, Hong J. Proprioceptive Neuromuscular Facilitation (PNF): Its Mechanisms and Effects on Range of Motion and Muscular Function. J Hum Kinet 2012;31:10513.

3. Takasaki H, Okubo Y, Okuyama S. The Effect of Proprioceptive Neuromuscular Facilitation on Joint Position Sense: A Systematic Review. J Sport Rehabil 2019;29:488-97.

4. Kofotolis N, Vrabas IS, Vamvakoudis E, Papanikolaou A, Mandroukas K. Proprioceptive neuromuscular facilitation training induced alterations in muscle fibre type and cross sectional area. $\mathrm{Br} \mathrm{J}$ Sports Med 2005;39:11.

5. Ninos J. PNF-Self Stretching Techniques. Strength \& Conditioning Journal. 2001;23:28.

6. Konrad A, Stafilidis S, Tilp M. Effects of acute static, ballistic, and PNF stretching exercise on the muscle and tendon tissue properties. Scand J Med Sci Sports 2017;27:1070-80.

7. Akbulut T, Agopyan A. Effects of an Eight-Week Proprioceptive Neuromuscular Facilitation Stretching Program on Kicking Speed and Range of Motion in Young Male Soccer Players. J Strength Cond Res 2015;29:3412-23.

8. Minshull C, Eston R, Bailey A, Rees D, Gleeson N. The differential effects of PNF versus passive stretch conditioning on neuromuscular performance. Eur J Sport Sci 2014;14:233-41.

9. Surburg PR, Schrader JW. Proprioceptive neuromuscular facilitation techniques in sports medicine: a reassessment. J Athl Train 1997;32:34-9.

10. Rhyu HS, Kim SH, Park HS. The effects of band exercise using proprioceptive neuromuscular facilitation on muscular strength in lower extremity. J Exerc Rehabil 2015;11:36-40.

11. Lazarou L, Kofotolis N, Pafis G, Kellis E. Effects of two proprioceptive training programs on ankle range of motion, pain, functional and balance performance in individuals with ankle sprain. J Back Musculoskelet Rehabil 2018;31:437-46.

12. Jonghwan C, Chulhyun R, Kyumoon L, Hyeonju K, Byeungok L. Effect of the PNF and weight training on flexibility, muscular strength, and power in college males. Journal of Motor Learning and Development 2003;11:35-43.

13. Marek SM, Cramer JT, Fincher AL, Massey LL, Dangelmaier SM, Purkayastha S, et al. Acute Effects of Static and Proprioceptive Neuromuscular Facilitation Stretching on Muscle Strength and Power Output. J Athl Train 2005;40:94-103.

14. Areas GP, Borghi-Silva A, Lobato AN, Silva AA, Freire RC Jr, Areas FZ. Effect of upper extremity proprioceptive neuromuscular facilitation combined with elastic resistance bands on respiratory muscle strength: a randomized controlled trial. Braz J Phys Ther 2013;17:541-6. 
15. Gachette R, Lauwers T. Grip \& Pinch Strength in Relation to Anthropometric Data in Adults. J Orthop Res Physiother 2018;4:17.

16. Fess EE. Grip Strength. In: Casanoca JS, editor. Clinical Assesment Recommendations. Chicago: American Society of Hand Therapists; 1992.p.41-5.

17. Dhahbi W, Chaabene H, Chaouachi A, Padulo J, G Behm D, Cochrane J, et al. Kinetic analysis of push-up exercises: a systematic review with practical recommendations. Sports Biomech 2018:1-40.

18. Coyne JOC, Tran TA, Secomb JL, Lundgren L, Farley ORL, Newton RU, et al. Reliability of Pull Up \& Dip Maximal Strength Tests. J Aust Strength Cond 2015;23:21-7.

19. Sharman MJ, Cresswell AG, Riek S. Proprioceptive neuromuscular facilitation stretching : mechanisms and clinical implications. Sports Med 2006;36:929-39.

20. Colado JC, Garcia-Masso X, Pellicer M, Alakhdar Y, Benavent J, Cabeza-Ruiz R. A comparison of elastic tubing and isotonic resistance exercises. Int J Sports Med 2010;31:810-7.

21. Young W, Elliott S. Acute effects of static stretching, proprioceptive neuromuscular facilitation stretching, and maximum voluntary contractions on explosive force production and jumping performance. Res Q Exerc Sport 2001;72:273-9.
22. Nelson AG, Kokkonen J, Arnall DA. Acute muscle stretching inhibits muscle strength endurance performance. J Strength Cond Res 2005;19:338-43.

23. Nelson AG, Guillory IK, Cornwell C, Kokkonen J. Inhibition of maximal voluntary isokinetic torque production following stretching is velocity-specific. J Strength Cond Res 2001;15:241-6.

24. Celenay ST, Kaya DO. Scapular Winging: Effects of Scapular Muscle Training with Proprioceptive Neuromuscular Facilitation Techniques on Shoulder Strength and Function. Orthop J Sports Med 2014;2:1.

25. Anakwe RE, Huntley JS, McEachan JE. Grip strength and forearm circumference in a healthy population. J Hand Surg Eur Vol 2007;32:203-9.

26. Nicolay CW, Walker AL. Grip strength and endurance: Influences of anthropometric variation, hand dominance, and gender. Int J Ind Ergon 2005;35:605-18.

27. Andersen TR, Schmidt JF, Nielsen JJ, Randers MB, Sundstrup E, Jakobsen MD, et al. Effect of football or strength training on functional ability and physical performance in untrained old men. Scand J Med Sci Sports 2014;24:76-85.

28. Black C, Lawrence W, Cradock S, Ntani G, Tinati T, Jarman M, et al. Healthy conversation skills: increasing competence and confidence in front-line staff. Public Health Nutr 2014;17:700-7. 